\title{
Tectonics and Evolutionary History of the Cretaceous Intra-arc Yongdong Basin, Korea \\ Dong-Woo Lee*
}

\author{
Department of Geoenvironmental Sciences, Kongju National University, Chungnam 314-701, Korea
}

\begin{abstract}
The Yongdong basin developed during Early Cretaceous in the central part of the Korean Peninsula and bounded on the northwest and southeast by northeast trending mega-scale strike-slip Yongdong Fault. An $8 \mathrm{~km}$ thick succession of exclusively terrigeneous sediments can be grouped into two mega-sequences. In concert with the migration of depocenter, the upper sequence overlaps the lower and occupies northern part of the basin during basin evolution. Alluvial and lacustrine environments were predominantly formed from early to late stage of the basin formation. Several lines of evidence support that the basin was formed within intra-arc tectonic environments and destroyed by polyphase tectonic force. Schematic evolutionary diagram of the basin is proposed
\end{abstract}

Keywords: strike-slip tectonics, intra-arc, migration of depocenter

\section{Introduction}

Tectonic, magmatic and volcanic activities along the East Asian continental margin produced a series of sedimentary, igneous, and volcanic rock successions on the Korean Peninsula. Widespread occurrences of small Cretaceous sedimentary basins have been recorded along the northeast-southwest trending megafaults on the Korean Peninsula. Cretaceous sediments in Korea are exclusively non-marine origin with large amounts of volcanogenic material.

Since the mid-1980s, the origin of these basins has been studied from the view point of strike-slip tectonics and various aspects of basin fill, such as basin geometry, subsidence history, climate, sediment source, drainage pattern, depositional mechanism, geological setting, and age. Stratigraphic and sedimentological characteristics of the Cretaceous basins on the Korean Peninsula are characterized by rapid vertical and lateral facies change over relatively short distance (Chang, 1977; Choi, 1986; Choi and Jin, 1988; Chun and Lee, 1991; Lee, 1990; Lee and Paik, 1989).

The Cretaceous Yongdong basin occupies an area of

*Corresponding author: cdpii@kongju.ac.kr

Tel: $82-41-850-8513$

Fax: 82-41-850-8953
$480 \mathrm{~km}^{2}$ and is developed between left-stepping en echelon sinistral strike-slip faults (Fig. 1). Yongdong basin deposits typically comprises more than $60 \%$ gravelstone with subordinate sandstone and siltstone. The gravelstone is either greenish gray or purple in color. Basin fills are divided into two mega-sequences by tectonic stage and sedimentological characteristics (Lee, 1990; Lee et al., 1991).

The lower mega-sequence is distributed mainly in the southern part of the basin, whereas the upper sequence in the northern part of the basin. The lower mega-sequence generally shows a simple finingupward trend consisting mainly of disorganized and massive gravelstones. Disorganized breccias and gravels occur at the base of the lower megasequnce. The sediments are overlain by black siltstone. Sediments of the lower megasequence are partly overlain by the sediments of the upper megasequence, and occupy a smaller area compared to the upper sequence.

The upper mega-sequence is composed of many cyclic fining-upward sequences. Paleocurrent directions, pebble composition and other sedimentological characteristics of the two sequences are different from each other (Lee and Paik, 1990). Major sedimentological characteristics of the two mega-sequences are summarized in Table 1. 
Table 1. Comparison of depositional characteristics between the two mega-sequences (after Lee, 1990)

\begin{tabular}{ccc}
\hline \hline Stage & Lower mega-sequence & Upper mega-sequence \\
\hline Paleocurrents & NW, SE & NW, SE, NE \\
Depositional Environments & Alluvial Lacustrine & Alluvial Lacustrine Fluvial \\
Intrabasinal Clast & None & Exist \\
Location & Southern Part & Northern Part \\
Volcanic clast & None & Exist \\
\hline
\end{tabular}

Basement geometry of the Yongdong basin was interpreted as asymmetric half-graben by gravity and magnetic data (Kwon and Kim, 1994) and by sedimentological interpretation (Lee and Paik, 1989, 1990). Stratigraphic studies of the study area were carried out by Simamura (1927), Son et al. (1969), Kim (1973, 1974, 1996), Kim and Hwang (1986) and Lee et al. (1991). Lee et al. (1991) divided the Yongdong Group into Mangyeri, Saniri, Dongjongri, Sonyudong and Wonchonri formations in ascending order. In general, the lower mega-sequence comprises Mangyeri and Saniri formations, whereas the upper mega-sequence comprises Dongjongri, Sonyudong and Wonchonri formations.

Lee (1990) and Kim (1996) analyzed sedimentary facies of northern and southern area of the basin, respectively. In this paper, reconstruction of paleogeography of the Yongdong basin, interpretation on depositional environments based on sedimentary facies analysis, and discussion on tectonic affinity which produced sedimentary basin during Cretaceous in the Korean Peninsula were emphasized, and a evolutionary diagram of the Yongdong basin is proposed.

\section{Tectonic Setting}

Precambrian crystalline rocks commonly form the basement of Cretaceous sedimentary basins on the Korean Peninsula. The basement is gneissic rock which has been interpreted as the continental remnants of an allochthonous terrane accreted to the North China Block during Silurian to Devonian (Cruzel et al., 1990). During Mesozoic, there was a NE-SW trending large-scale right-handed ductile shear zone in the south-central Korean Peninsula (Yanai et al.,
1985).

Korean Peninsula has been an active continental margin since Late Jurassic. At the end of the Jurassic, major fault movement took place along the Asian continental margin by collision of northward-moving South China Block and North China Block (Yin and Nie, 1993). After the indentation tectonics over the ancient Asian continent sedimentation and magmatic activities took place mainly by the subduction of the Kula plate, creating a large-scale sinistral strike-slip fault system. The system consists of three major sinistral strike-slip faults; the Sikhote-Alin fault system in Far East Russia (Utkin, 1975, 1984, 1993), the Tan$\mathrm{Lu}$ fault system in China (Xu et al., 1987), and the Kongju and Yongdong fault system in Korean Peninsula (Lee, 1998). The system has close spatial and temporal relationships with geodynamic evolution and sedimentary basin formation along the border of the Asian continent (Lee, 1998; Utkin, 1993). During the Early Cretaceous, continued subduction of Kula plate/Pacific plate beneath the Asian continental margin yield northward compressional stress along the Asian continental margin (Cui et al., 1985; Hilde et al., 1977).

As a part of the Asian Terrane, the Korean Peninsula has not been subjected to any rotational movements since Cretaceous (Kim et al., 1990; Lee et al., 1987), but experienced subduction related magmatic activity and crustal deformation from the Early Cretaceous to Early Tertiary (Kim et al., 1991; Klimetz, 1983; Lee, 1994; Lee and Kim, 1990; Park et al., 1997; Watson et al., 1987).

The Early Cretaceous volcanic zone lies to the east of the deep-seated Tan-Lu fault and consists mainly of rhyolite, ignimbrite, tuff and other intermediate-acidic rocks (Chen, 1993). During middle to late Early 
Table 2. Summarized facies description and interpretation of the northern (after Lee, 1990; Lee et. al., 1992) and southern part (after Kim, 1996) of the Yongdong basin

\begin{tabular}{|c|c|c|}
\hline Facies & Description & Processes and environment \\
\hline \multicolumn{3}{|c|}{ Northern part (after Lee, 1990; Lee et. al., 1992) } \\
\hline $\begin{array}{l}\text { Disorganized, massive, } \\
\text { Homogeneous } \\
\text { breccia (B) }\end{array}$ & $\begin{array}{l}\text { Angular, disorganized matrix-supported gravels with purple } \\
\text { sandy matrix, non-erosive base, commonly fining-upward }\end{array}$ & $\begin{array}{l}\text { Debris flow (Lewis et al., 1980) and } \\
\text { waning debris flow (Steel, 1974) }\end{array}$ \\
\hline $\begin{array}{l}\text { Disorganized, massive } \\
\text { Gravelstone } \\
(\mathrm{Gd})\end{array}$ & $\begin{array}{l}\text { Disorganized and poorly sorted, bedding planes are difficult to } \\
\text { recognize, slight normal- and inverse-grading, predominant } \\
\text { sand-sized matrix primarily pebble- to cobble-sized clast }\end{array}$ & $\begin{array}{l}\text { Debris flow (Bull, 1972; Miall, 1978; } \\
\text { Walker, 1975). High viscosity and den- } \\
\text { sity mass movement (Fisher, 1971) }\end{array}$ \\
\hline $\begin{array}{l}\text { Cross-, and } \\
\text { Horizontally-stratified gravel- } \\
\text { stone (Gs) }\end{array}$ & $\begin{array}{l}\text { Poor sorting, crude stratification inverse and normal grading, } \\
\text { matrix-supported, internal stratification is defined by pebble } \\
\text { alignment }\end{array}$ & $\begin{array}{l}\text { Sheet flow (Allen, 1981; Ballance, } \\
\text { 1984; Koster, 1978) }\end{array}$ \\
\hline $\begin{array}{l}\text { Poorly stratified, graded gravel- } \\
\text { stone }(\mathrm{Gg})\end{array}$ & $\begin{array}{l}\text { Poorly to moderately sorted, matrix-supported, distinct or } \\
\text { slightly erosive base, fining-upward, interbedded with planar } \\
\text { sandstone, siltstone and stratified gravelstone }\end{array}$ & $\begin{array}{l}\text { Longitudinal fan deposits (Allen, 1981; } \\
\text { Mader, 1985; Rust, 1972; Smith, 1974) }\end{array}$ \\
\hline $\begin{array}{l}\text { Weekly stratified and } \\
\text { graded gravelstone (Gsg) }\end{array}$ & $\begin{array}{l}\text { Planar and trough cross-stratification, matrix-supported, rounded } \\
\text { and poorly sorted granulstone, thin and lensoidal layers of } \\
\text { gravelstone, highly erosive base }\end{array}$ & $\begin{array}{l}\text { Stream dominated alluvial fan (Boo- } \\
\text { throyd, 1972). Braided stream (Cant and } \\
\text { Walker, 1976; Miall, 1977, 1978; Rust, } \\
\text { 1978; Williams and Rust, 1969) }\end{array}$ \\
\hline $\begin{array}{l}\text { Massive, homogeneous pebbly } \\
\text { sandstone } \\
\text { (Smp) }\end{array}$ & $\begin{array}{l}\text { Lensoidal bed, overlies gravel facies }(\mathrm{G}) \text { and/or underlies } \\
\text { homogeneous siltstone (Sh), locally interbeds with laminated } \\
\text { and cross-stratified units, commonly scoured base }\end{array}$ & $\begin{array}{l}\text { Flat-topped longitudinal bar (Rust, 1972; } \\
\text { Smith, 1971). }\end{array}$ \\
\hline $\begin{array}{l}\text { Massive, homogeneous } \\
\text { Sandstone }(\mathrm{Sm})\end{array}$ & $\begin{array}{l}\text { Lack of visual stratification, lensoidal beds, interbedded with } \\
\text { pebbly sandstone or siltstone, granule lags are common at each } \\
\text { bottom }\end{array}$ & $\begin{array}{l}\text { Longitudinal sandy bar under very high } \\
\text { energy condition (Miall, 1977; Rust, } \\
\text { 1972; Reinek and Singh, 1980; Smith, } \\
\text { 1971). }\end{array}$ \\
\hline $\begin{array}{l}\text { Laminated, } \\
\text { planar- and } \\
\text { cross-stratified sandstone }(\mathrm{Sc})\end{array}$ & $\begin{array}{l}\text { Horizontal to low-angle cross-stratification, commonly extends } \\
\text { laterally up to } 4 \mathrm{~m} \text {, trough cross-stratification units overlie } \\
\text { massive and stratified gravelstone, commonly overlain by mas- } \\
\text { sive or stratified gravelstone }\end{array}$ & $\begin{array}{l}\text { Longitudinal bar or lateral migration of } \\
\text { channels (Collinson, 1970; Cant and } \\
\text { Walker, 1976; 1978). }\end{array}$ \\
\hline Homogeneous siltstone (Sh) & $\begin{array}{l}\text { Purple, calcareous nodules, interbedded with gravelstone and } \\
\text { sandstone by planar contact, contain granule-size clasts }\end{array}$ & $\begin{array}{l}\text { Overbank or subaerially exposed over- } \\
\text { bank (Allen, 1981; Lorentz, 1980; } \\
\text { Mader, 1985; McPherson, 1979; Miall, } \\
\text { 1977; Speksnijder, 1985; Turner, 1980). }\end{array}$ \\
\hline \multicolumn{3}{|l|}{ Southern part (after Kim, 1996) } \\
\hline $\begin{array}{c}\text { Disorganized, } \\
\text { Clast-supported } \\
\text { Conglomerate }(\mathrm{Cc})\end{array}$ & $\begin{array}{l}\text { Clast-supported, pebble to boulder-grade clast, lack internal } \\
\text { organization, poorly sorted, medium- to pebbly coarse-grained } \\
\text { sand matrix, thin- to thick-bedded, flat or scoured bases }(<0.6 \\
\mathrm{m} \text { in depth); wedge, lobate or sheetlike geometry, occasional } \\
{[\mathrm{a}(\mathrm{p}), \mathrm{a}(\mathrm{i})] \text { imbrication; matrix content commonly increases }} \\
\text { upward, rare vertical clast orientation }\end{array}$ & $\begin{array}{l}\text { Cohesionless debris flows (Lowe, } \\
\text { 1982; Nemec and Steel, 1984; Postma, } \\
\text { 1986; Nemec, 1990), } \\
\text { Hyperconcentrated flows (Smith, 1986; } \\
\text { Costa, 1988). }\end{array}$ \\
\hline $\begin{array}{l}\text { Disorganized, } \\
\text { Matrix-supported } \\
\text { Conglomerate } \\
\quad(\mathrm{Cm})\end{array}$ & $\begin{array}{l}\text { Matrix-supported, pebble to boulder-grade clast, poor internal } \\
\text { organization, poorly sorted, muddy sand or pebbly coarse- } \\
\text { grained sand matrix, thin- to thick- bedded, non-erosive or } \\
\text { scoured base }(<0.3 \mathrm{~m} \text { in depth), lobate or wedge geometry, } \\
\text { matrix content commonly increases upward }\end{array}$ & $\begin{array}{l}\text { Cohesionless debris flows (Lowe, 1976a, } \\
\text { 1982; Nemec and Steel, 1984; Postma, } \\
\text { 1986), plastic debris flows (Gloppen and } \\
\text { Steel, 1981; Shultz, 1984; Postma, 1986; } \\
\text { Costa, 1988). }\end{array}$ \\
\hline
\end{tabular}

Cretaceous, sinistral fault systems consisting of numerous left-stepping en echelon strands produced many small grabens or half grabens in Korean Peninsula (Lee, 1998). 
Table 2. Continued

\begin{tabular}{cll}
\hline \hline Facies & \multicolumn{1}{c}{ Description } & \multicolumn{1}{c}{ Processes and environment } \\
\hline (Crudely) & Clast- or matrix-supported, granule to cobble-grade clast; & Cohesionless debris flows/ density modi- \\
stratified & poorly to moderately sorted, coarse- to medium-grained sand & fied grain flows (Middleton and Hamp- \\
conglomerate & matrix; common a- or b-axis imbrication; thin- to thick-bed- & ton, 1976; Lowe, 1982; Surlyk, 1984), \\
(Cs) & ded; flat or scoured bases $(<0.5 \mathrm{~m}$ in depth); occasional & deposits sheet bars, longitudinal bars \\
& coarse-tail grading; intercalating well-defined, layer; com- & (Hein and Walker, 1977), Hyperconcen- \\
& monly underlain by Cc and Ci, overlain by Sh Sm and Sn & trated flows (Smith, 1986; Wells and \\
& & Harvey, 1987; Costa, 1988).
\end{tabular}

Inversely- or Inverse-toNormally graded conglomerate $(\mathrm{Ci})$

Normally
Graded
Conglomerate
(Cn)

Massive
(gravelly)
sandstone (Sm)

Horizontally
Stratified
(gravelly)
sandstone (Sh)

\footnotetext{
Planar cross-

Stratified

(gravelly)

sandstone (Sp)

Trough cross-

Stratified

(gravelly)

sandstone (St)

Normally

Graded

Sandstone (Sn)

Inversely
Graded
Sandstone (Si)
}

Laminated

Sandstone (Sl)
Clast- or matrix-supported, pebble to boulder-grade clast; base- Cohesionless debris flows/density modito-top or basal inverse grading; common [a(p), a(i)] imbrica- fied grain flows (Lowe, 1982; Nemec tion; thin- to thick-bedded; flat or scoured base $(<0.5 \mathrm{~m}$ in and Steel, 1984), pseudo- plastic debris depth); rare normal grading in the upper part; medium- to peb-flows (Shultz, 1984).

bly coarse-grained sand matrix; matrix content commonly increases upward

\begin{abstract}
Clast- or matrix-supported, pebble to cobble-grade clast; base- Gravelly high-density turbidity currents to-top normal grading; thin- to thick-bedded; erosive or uneven (Lowe, 1982), pseudo-plastic or cohebase; medium- to pebbly coarse-grained sand- matrix; parallel sionless debris flows (Nemec and Steel, oriented elongate clast; matrix content commonly increases 1984; Shultz, 1984). upward
\end{abstract}

Massive, fine- to gravelly coarse-grained sandstone; thin- to thick-bedded; partly widely dispersed granules; poorly sorted; normal grading in the basal imentation from heavily sand-laden part flows (Maizel, 1993).

Horizontal stratification, poorly to moderately sorted, medium- Bed-load traction currents; high to gravelly coarse-grained sandstone, commonly contain thin Density turbidity currents (Nemec et al., (one or two clasts thick), tightly packed, impersistent granule 1984; Postma, 1984; Chun and Chough, to pebble layers; rare scour features; thin- to thick-bedded; 1992a); hyperconcent-rated flows rarely includes isolate, outsized pebbles; commonly underlain (Smith, 1986); rapid sedimentation from by $\mathrm{Cc}$ and $\mathrm{Cs}$; overlain by $\mathrm{Sm}$.

high sand-laden flows (Allen, 1981; Maizel, 1993).

Crude to distinct, planar cross-stratification; poorly to moderately sorted; medium- to gravelly coarse-grained sandstones; thin- to thick-bedded; tabular to wedge shaped unit; commonly underlain by $\mathrm{Cc}$, overlain by $\mathrm{Sh}$

Avalanching by tractive flows or migration of 2D dunes (Hein and Walker, 1977; Miall, 1977, 1978; Rust, 1978).

Crude to distinct, trough cross-stratification; poorly to moder- Avalanching by tractive flows or migraately sorted; medium- to gravelly coarse-grained sandstones; thin- to thick-bedded; commonly underlain by Sh and Sp.

Normally graded, poorly to moderately sorted, fine- to very tion of 3D dunes (Hein and Walker, 1977; Rust, 1978), Channel pool filling (Harms et al., 1982).

coarse-grained sandstones; thin- to medium-bedded; granule to High- or low-density turbidity currents fine pebble clasts at base.

(Lowe, 1982; Nemec and Steel, 1984).

Poorly to moderately sorted, fine- to very coarse-grained sand- Traction carpet sedimentation under stones; fine to medium sand at base, coarse sand to granule rapid suspension settling (Lowe, 1982). near the top; individual units are mostly capped by thin veneers of mud; thin-bedded,

Moderately to well sorted, fine- to medium-grained sandstone; Low-density turbidity currents (Lowe, alternation of fine to coarse-grained laminae, commonly red- 1982), lower flow regime plane bed dish; thin- to medium-bedded.
Structural characteristics and geophysical evidence support that the Yongdong fault (Yongdong-Kwangju fault line) is regarded to be one extension of the central Primorsky fault system (central Sikhote-Alin 
Table 2. Continued

\begin{tabular}{cll}
\hline \hline Facies & \multicolumn{1}{c}{ Description } & \multicolumn{1}{c}{ Processes and environment } \\
\hline $\begin{array}{c}\text { Sandstone- } \\
\text { Mudstone } \\
\text { Couplet (SM) }\end{array}$ & $\begin{array}{l}\text { Alternation of thin sandstone and mudstone layers (mudstone } \\
\text { prevailing); thin- to thick-bedded; commonly overlain by Md; } \\
\text { rarely interlayered with wedged Sm, Sl. }\end{array}$ & $\begin{array}{l}\text { Suspension fallout from low-density tur- } \\
\text { bidity currents (Lowe, 1982; Allen, } \\
\text { 1984; Walker, 1985). }\end{array}$ \\
$\begin{array}{c}\text { Dark (greenish) } \\
\text { gray mudstone (Md) }\end{array}$ & $\begin{array}{l}\text { Thin- to thick-bedded; dark gray or greenish gray; homoge- } \\
\text { neous or diffuse parallel lamination; occasional calcareous nod- } \\
\text { ules or thin calcareous lenses. }\end{array}$ \\
Red & $\begin{array}{l}\text { Thin- to thick-bedded; reddish brown; poorly sorted; homoge- Overbank suspension fallout. } \\
\text { neous; common dispersed gravels, gravel trains, and calcare- }\end{array}$ \\
ous nodules; common intercalation of tabular sandstones; & \\
Mudstone (Mr) & irregular shaped mottles and pedogenic slickensides. & \\
&
\end{tabular}

fault and Vostochny fault). The fault is most likely continuous to the Changle-Nanao fault zone in southeastern China (Emery et al., 1969, Lee, 1998; Utkin, 1984, 1993). Some small basins are regarded to be associated with the junctions of the Yongdong fault and appear to be produced within horst and/or graben by the segmentation of the branching Yongdong fault. The fault plane dips from $70^{\circ}$ to vertical (Kwon et al., 1993; Lee, 1990). Amount of vertical throw along the Yongdong fault varies from place to place suggesting the presence of block faulting in the basement of the Yongdong basin.

\section{Sedimentary Facies}

Sedimentary facies analysis of the Yongdong basin carried out by Lee (1990), Lee et al., (1992) and Kim (1996). Lee (1990) and Lee et al., (1992) mainly studied the northern part and Kim (1996) focused on the southern part of the basin (Table 2).

\section{Depositional Environments}

\section{Upper mega-sequence (northern area)}

Three facies associations are organized based on field occurrence, frequency of individual facies and facies transition (Lee et al., 1991). Facies distribution of the upper mega-sequence of the Yongdong Group (Dongjongri, Sonyudong and Wonchonri formations) shows a systematic change from basin margin to center. It can be divided into three facies associations, suggesting sedimentation on alluvial fan, alluvial plain and fluvial environments (Table 3). The alluvial fan facies association is basically restricted to the basin margins, whereas the alluvial plain and fluvial association is typical for the central parts of the basin.

Alluvial fan environments: Alluvial fans developed along longitudinal basin margin. The southeastern alluvial fans are small in its dimension compared to those of the northwestern margin. The alluvial fan

Table 3. Facies association and depositional environments of the Yongdong basin

\begin{tabular}{cccc}
\hline \hline & $\begin{array}{c}\text { Facies } \\
\text { Association }\end{array}$ & $\begin{array}{c}\text { Comprising Facies } \\
\text { (Minor components) }\end{array}$ & $\begin{array}{c}\text { Depositional } \\
\text { Environment }\end{array}$ \\
\hline $\begin{array}{c}\text { Northern Area } \\
\text { (Upper mega-sequence) }\end{array}$ & FA I & B, Gs, Gd, Gg (Sc, Smp, Sh) & Alluvial Fan \\
& FA II & Gg, Gd, Gsg, Gs, Sm, Smp (Sc, Sh) & Alluvial Plain \\
& FA III & Gsg, Sm, Smp, Gg, Sc (Sh) & Braided/Fluvial System \\
\hline Southern Area & FA I & Cc, Cm, Cs, Sh (Sm, Sp, Mr) & Alluvial Fan \\
(Lower mega-sequence) & FA II & Cc, Cm, Cs, Ci, Sh, Sm (Cn, Sp, Sn) & Delta Slope \\
& FA III & Cc, Cs, Sh, St, Sp, Sm (Sl, Mr) & Floodplain / Lake \\
\hline
\end{tabular}


facies association consist predominantly of facies B, Gd, Gs with minor Smp. The facies association is commonly restricted to the basinal margin.

Within this association, sharp lower boundaries are present. Sediments of this association are interpreted as accumulation on alluvial fans built out from the margin. Proximal debris flow deposits were later buried by mid to distal fan deposits. Facies Gm, Gd, and Gs reflect deposits of proximal to medial alluvial fan facies characterized by high depositional slope angle. Facies Gsg, Smp, Sm and Sh represent the medial to distal fan. All these features are interpreted as a result of progradation and retrogradation of alluvial fans due to changes in tectonic, geomorphologic, climatic conditions as well as the rate of sediment supply (Lee et al., 1992).

Alluvial plain environments: Alluvial plain facies association covers about $40 \%$ of the basinal area and consists predominantly of facies Gg, Gsg, Smp and $\mathrm{Sm}$, and minor of facies Gs, Gd and Sc. Continued aggradation in the channel and/or migration of a bar over the channel resulted in deposition of facies $\mathrm{Gg}$, Gsg, Smp, Sm, Sc and Sh. Most of the sequences exhibit a fining upward trend, which reflects transition from relatively proximal to distal parts. Depositional cycles recognized in vertical succession suggest that one or more channels migrated across the alluvial plain. The cycles range in thickness from 2 to $10 \mathrm{~m}$, and are characterized by; 1) basal coarse-grained beds of facies Gg, Gsg, Gd and Smp deposited on channel; 2) relatively fine-grained facies $\mathrm{Sm}$ and $\mathrm{Sc}$ or overbank deposits represented by facies Sh. This association is interpreted to represent alluvial plain containing a braided complex of smaller channels with associated interchannel and overbank deposits.

Fluvial deposits: Fluvial environments were developed along the basinal longitudinal direction. Fluvial environments consist predominantly of facies Sc and Sh. This association is restricted to the central part of the basin occupying less than $20 \%$ of the total exposure. Fining- and thinning-upward depositional cycles are interpreted to represent degradation or lateral migration of associated channels. The association represents a gradual filling of channel complex with planar upper beds of facies Gg, Gsg and Smp as well as continued aggradation and migration of bars.

\section{Lower mega-sequence (southern area)}

Six distinct lithologic units are distinguished and mapped. Based on spatial changes in facies occurrences and geometry, these lithologic units can be organized into four facies associations representing four distinctive depositional environments: alluvial fan, delta slope, braided stream, floodplain/lake (Table 2). Following is the summary of Kim (1996).

Alluvial fan environments (FA I): The FA I is characterized by laterally discontinuous granule-toboulder-size gravelstone (facies $\mathrm{Cc}, \mathrm{Cm}$ and $\mathrm{Cs}$ ) and crudely stratified or massive gravelly sandstone (facies $\mathrm{Sh}, \mathrm{Sp}$ and $\mathrm{Sm}$ ). The facies units are generally arranged in a fining-upward trend, decimeters to more than $3 \mathrm{~m}$ thick. Underlying gravelstone and overlying crudely stratified or massive gravelly sandstones represent individual fining-upward unit. The gravelstone and gravelly sandstones rest on sharp-based, unchannelized or concave-up erosive base, forming sheet-like or wedged hollow-fill unit.

The FA I occurs along the basin margin, forming the lithologic units IIa-i (gravelstone/gravelly sandstone) and IIIa-b (gravelly sandstone) included in the lower part of the Mangyeri, Saniri (Gagguyeri), and Dongjongri alloformations. This association shows radial distribution pattern and grade into FA II and FA III toward the basin center.

The association I can be interpreted as subaerial, alluvial fan deposits which accumulated both in broad, gravel-bed fan-channels and on unchannelized aggrading fan surfaces (Miall, 1978; Rust and Koster, 1984). The predominant sheet-like bodies of gravelstone and gravelly sandstone alternating with fine-grained sediments ranging in thickness from several meters to tens of meters suggest the 
dominance of vertical aggradation of alluvial fan deposits (e.g., Heward, 1978; Decelles et al., 1991).

Delta slope environments (FA II): This association consists of decimeters to $2.0 \mathrm{~m}$ thick, pebble-toboulder-size gravelstones (facies $\mathrm{Cc}, \mathrm{Cm}, \mathrm{Cs}, \mathrm{Ci}$ and $\mathrm{Cn}$ ) and a few $\mathrm{cm}$ to $2.5 \mathrm{~m}$ thick (crudely) stratified (laminated), graded and massive (gravelly) sandstones (facies Sh, Sl, Sn and Sm). Gravelstone units are laterally impersistent with wedge or lobe shape. These units are bounded by sharp, flat or erosive concave-up base, and diffused convex-up top. Throughout the successions, crudely horizontally stratified gravelly sandstones (facies Sh) are commonly interbedded by even alternation of thin, gravelly sand sheet and poorly to well sort sand layers.

The common scoured bases, whose infills form laterally impersistent conglomerate beds, is indicative of low-sinuosity channel/chute running down the delta slope face (Postma and Cruickshank, 1988). Gravelstones with lobate geometry can be interpreted as subaqueous depositional lobes, which commonly occur in delta or slope environments (Prior and Bornhold, 1988, 1989, 1990; Postma and Cruickshank, 1988). The crudely stratified gravelly sandstone (facies $\mathrm{Sh}$ and $\mathrm{Sc}$ ) could develop under conditions of high rates of bed-load transport accompanied by a cloud of suspension, moving at a high speed (Mastalerz, 1995). Some graded and crudely stratified units were most probably settled from high-concentration and turbulent suspension in which fluctuation of the flow led to the high rate traction sedimentation (Chun and Chough, 1992a; Mastalerz, 1995).

Braided stream environments (FA III): The association III consists of crudely stratified (facies Cs) and disorganized, clast-supported (facies $\mathrm{Cc}$ ) gravelstones. Horizontally stratified (gravelly) sandstone (facies Sh), planar cross-stratified gravelly sandstone (facies $\mathrm{Sp}$ ), trough cross-stratified gravelly sandstone (facies $\mathrm{St}$ ), laminated sandstone (facies $\mathrm{Sl}$ ) are common with subordinate disorganized gravelstone (facies $\mathrm{Cc}$ and $\mathrm{Cm}$ ) and massive gravelly sandstone (facies $\mathrm{Sm}$ ).
The facies units are arranged in a fining-upward trend (decimeters to more than $5 \mathrm{~m}$ ) resting on an erosive base. They are vertically and laterally accreted forming sheet-like geometry. The basal part of individual fining-upward units consist of crudely stratified or disorganized, clast-supported gravelstones. They are vertically and laterally transitional to (gravelly) sandstones. Lateral continuity of each bed usually extends less than $20 \mathrm{~m}$.

Concave-upward gravelstone beds, relatively welldeveloped stratification of the (gravelly) sandstone beds and common lateral accretion of package suggest that the facies association may represent deposition in migrating confluent channels, and traction and accretion on the upper flow regime plane beds in braided stream (Smith, 1974; Miall, 1977, 1978; Boothroyd and Nummedal, 1978; Bluck, 1980). Disorganized and crudely stratified conglomerate beds (facies Cc and Cs) were mostly deposited on gravel bars during flooding stage (Rust, 1978). The finingupward units bounded by erosive bases, dominance of crude stratification, and the rare reactivation surfaces within a package indicate that the braided channels were ephemeral (Bentham et al., 1993).

Flood plain, lacustrine environments (FA IV): The association IV consists mainly of decimeters to several meters thick, reddish (silty) mudstone (facies $\mathrm{Mr}$ ), dark (greenish) gray mudstone (facies $\mathrm{Md}$ ), and sandstone-mudstone couplet (facies SM) interbedded with a few cm's to decimeter's thick tabular or wedged sandstone bed. The red mudstone generally forms decimeters to several meters thick sequence alternating with a few or several tens of meters thick sheets of gravelstone and (gravelly) sandstone of FA I and FA III.

Mud-dominated lithology and its inferred distal paleogeographical position suggest that FA IV formed in a floodplain/lake environment. Reddish mudstone was accumulated in floodplain subenvironment probably as overbank deposits during abandonment of coalescing stream channels (Miall, 1978; Rust, 1978). The isolated disorganized/crudely stratified gravelstones 


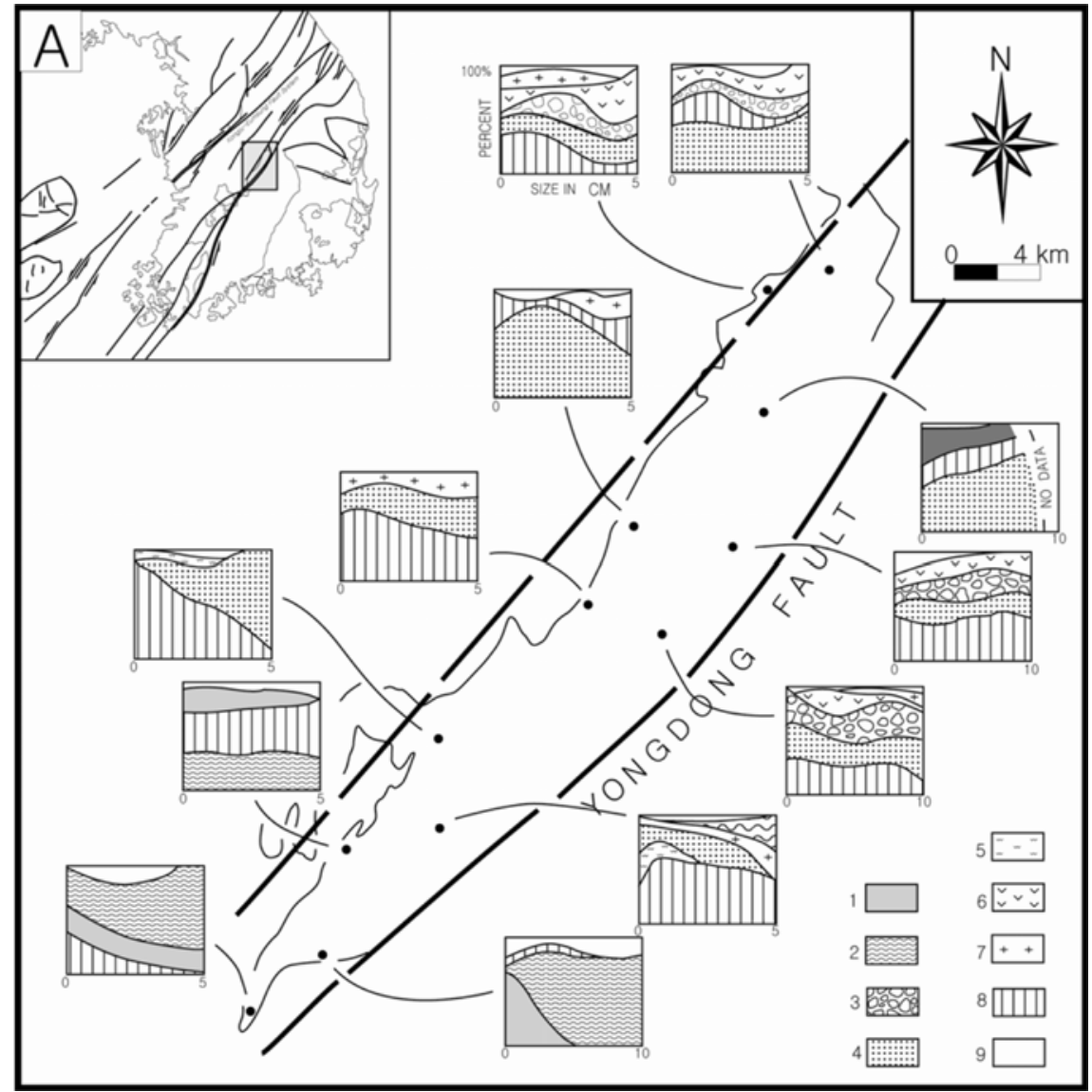

Fig. 1. Index map (A) and clast composition in the Yongdong Basin. Horizontal lines represent size of sediments and vertical lines represent percentage of the sediments, respectively. 1: Schist, 2: Gneiss, 3: Gravelstone, 4: Arenite, 5: Vein quartz, 6: Andesite, 7: Granite, 8: Quartzite, 9: Others.

and (gravelly) sandstones are similar to crevasse-splay deposits, which overflowed from the active channel during intense flash flooding (Costa, 1974; Ritter, 1975). Homogeneous dark mudstone (facies Md) may result from slow suspension settling or diluted turbidity currents (Pickering et al., 1986).

In the basin margin, decimeters to several meters thick, reddish mudstone beds alternates with FA III or I, forming alluvial deposits. Toward the basin center, reddish mudstone beds gradually decrease and alternate with greenish or dark gray mudstone beds with abundance calcrete and wave ripples. The transition indicates basinward change in depositional system from alluvial fan to lacustrine (e.g., Lee, 1990).

\section{Composition of pebbles}

Distribution of clast composition in the Yongdong basin is shown in Fig. 1. The geology of the northwestern area to the Yongdong basin is occupied by greenschist to amphibolite facies of metasedimentary rocks including pelite and psammite, and basement gneissic rocks occupy the southeastern area. The northeastern and southwestern boundaries are in contact with the age unknown (Jurassic ?) deformed granite.

In each locality, 200-300 clasts, which are larger than $1 \mathrm{~cm}$ in diameter, were identified by hand-lens in the field. Conspicuous lithologic discrepancies are found from the two longitudinal margins and from the 
two mega-sequences (Fig. 1). Conglomerates at the southeastern margin commonly contain considerable amounts of gneiss, schist, granitic gneiss, and quartzite pebbles. The pebble of gneissic rock found in the southwestern marginal area of the basin seems to be deposition of in situ sediments. Pebbles of quartzite and meta-sedimentary rocks are dominant in the northwestern margin, whereas, purple sandstone and black shales remain as minor constituents. Some of the arenites are pebbly sand, purple sandy shales and black shales. These sedimentary clasts are of the upper and lower mega-sequence origin (Lee, 1990). They are presumably originated from the intrabasinal deposits.

The discrepancy in pebble composition in the basin appear to resulted from the different drainage system on both longitudinal flank and the subsequence changes in depositional environments during the two sequential deposition-period. The measurement not only establishes the source rock type and the general paleocurrents direction but also implies the meaningful movement pattern related to the formation of the sedimentary basin (Lee, 1990; e.g. Reading, 1980).

\section{Tectonics and basin formation}

The continued indentation tectonics from Early Permian produced a gigantic horizontal displacement of the Tan-Lu fault system (Yin and Nie, 1993), until Late Jurassic. After the continent-continent collision, Asian plate host subduction related tectonic environments resulted by northward Kula/Pacific plate motion since Early Cretaceous (Ben-Avraham, 1989; Hilde et al., 1977; Klimetz, 1983; Xu et al., 1987). As a result, a large-scale NE-SW trending sinistral strikeslip fault-prevailed zone occurred, and produced simple shear and transtension along the interior of the Asian continent (Chun and Chough, 1992b; Lee and Paik, 1990; Liu, 1984; Otsuki, 1992; Utkin, 1975, 1978, 1993; Xu et al., 1987).

A series of major sinistral wrench fault system, which shows straight and steep attitude, developed mainly in the southern part of the Korean Peninsula by the northward movements and subduction of the plates. As a result, two major strike-slip faults developed during Cretaceous in Korean Peninsula. One is Yongdong-Kwangju Fault (Yongdong fault) by which Yongnam massif (autochthonous terrane) is in contact with Okcheon Fold Belt. The other is KongjuEumseong Fault (Kongju fault). Northern margin of the OFB is in contact with Kyounggi massif (allochthous terrane) by Kongju fault. Both Yongdong and Kongju faults show left-lateral displacement of least order of 50 km (Lee, 1990; Lee and Paik, 1990). Origin and evolution of the most Cretaceous sedimentary basins are closely related with the two sinistral strike-slip faults (Kim, 1996; Lee, 1990; Lee, 1992; Lee and Paik, 1990).

By the sinistral tectonic movements of the Yongdong fault, Yongdong basin started to open, and sediments were transported toward the basin center which are composed mainly of alluvial fan gravelstones (Mangyeri Formation). After the infilling, a break in tectonic movement yields to stop sedimentation and made a standing body of water during the late stage of the lower mega-sequence. A closed lacustrine system was developed and occupied an extensive area simultaneously. During the late stage of the tectonic recession large volume of plants and black shales were deposited, which are designated as the Saniri Formation. (Fig. 2). The transitional zone from alluvial fan gravelstones (Mangyeri Formation) to lacustrine black shale (Saniri Formation) extends to a very narrow area and shows abrupt sedimentary facies changes (Fig. 2).

Steel and Gloppen (1980) report that fault zone along which strike-slip basins developed commonly has a greater degree of movement along one edge than the other fault. By the rejuvenation of tectonic movements and continuing strike-slip movements along the Yongdong fault which has a greater degree of movement than the northwestern boundary fault, the basin was pulled and apart parallel to the strike of the Yongdong fault yielding a northeastward extension of the basin (Lee, 1990; Lee and Paik, 1990).

Dimensional variation of alluvial fans between the two basinal margins can be explained by faster 


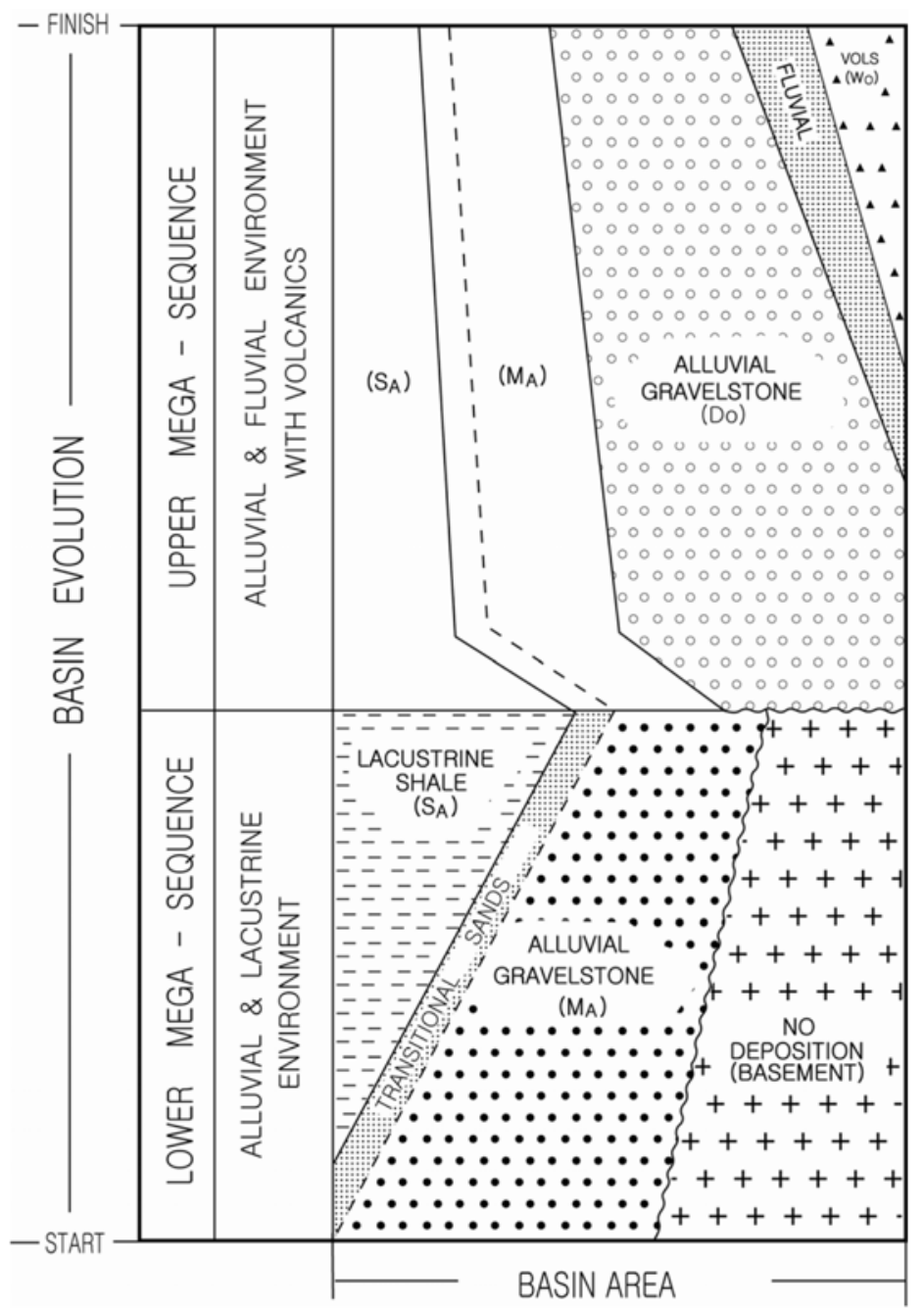

Fig. 2. Interpretative evolutionary diagram of the Yongdong Basin. Wavy lines show unconformity. Unornamented area shows pre-deposition. Ma: Mangyeri, Sa Saniri, Do: Dongjongri, Wo: Wonchonri formation.

subsidence in the southeastern margin compared with that of the northwest (Lee and Paik, 1990). As a result, both sediment thickness and facies distribution show a marked asymmetry. Patterns of the biased distribution of sedimentary facies in the basin (Lee, 1990), and the northeastward extension of the basin are evidences of asymmetric formation of basement structure during the basin evolution. The area of the Yongdong basin of this period is narrower than that of the present (Fig. 2).

Together with the rejuvenation, a new depocenter was developed, where sediments of the upper mega- sequence were deposited. Sediments deposited in this stage are commonly reddish to purple in color, and contain little lacsutrine shales. Locally, sediments of this stage cover the sediments of the lower sequence by intra-basinal unconformity (Lee and Paik, 1990). Large volume of infilling sediments with extensive drainage system on source terrain and pulsation of tectonic movements yield a longitudinal channel system along which standing body of water of the lower mega-sequence and currents from nearby highland flowed toward the direction of basinextension. Longitudinal fluvial system occupies eastern 
part of the basin axis.

Predominant depositional environments of this period are regarded as alluvial and alluvial plain. Many kinds of facies from alluvial to fluvial, proximal to distal, massflow to lacustrine facies are observed. Furthermore, individual facies have a limited lateral extent and there are evidences for the nearby active source area, which frequently provide the restricted deposition of locally derived conglomerates and breccias. These characteristics can be suggestive of transtensional strike-slip tectonics (Aspler and Donaldson, 1985; Ballance and Reading, 1980; Bluck, 1980; Heward, 1978; Nilsen and McLaughlin, 1985; Prebble, 1980; Reading, 1980; Steel et al., 1977; Steel and Gloppen, 1980; Zalan and Davis, 1985).

The subduction mode of the Kula/Pacific plate changed from oblique to normal, and tectonic mode changed drastically causing the intrusion of granite and the eruption of acidic volcanic rocks during Late Cretaceous (Kim et al., 1991; Otsuki, 1992; Sakai and Okada, 1997). The paleo-stress field of the strike-slip tectonics formed during the Early Cretaceous and lasted to the late stage of the basinal evolution may trigger vertical fractures to penetrate to a deep crustal level and offered magma with conduits to reach the surface. Consequently it is natural that there is a great deal of volcanic and volcanogenic sediments at the top of the Cretaceous sequences.

For example, the Kyeongsang basin, which is the largest Cretaceous basin in Korea, filled with $10-\mathrm{km}$ thick sediments which the top $2 \mathrm{~km}$ interval is volcanogenic sediments. The thick succession of continental red-beds and volcanogenic sediments were probably deposited on crustal depression within this magmatic arc. The volcanic belong to high-K calcalkaline suites in composition, and originated from subduction related magmatic activity (Kim et al., 1991; Kim and Lee, 1993; Park et al., 1997). The rate of sedimentation in the Kyongsang basin is as high as $1 \mathrm{~m}$ per thousand years during the Cretaceous.

Non-marine sediments, voluminous volcanogenic sediments, high rate of sedimentation, and similar tectonic environments during Cretaceous times characterize basins in the Korean Peninsula. Rapid subsidence of crust, extensional faulting, and exclusively non-marine sedimentation are ascribed to block faulting resulting from intra-arc extension (Lee, 1998). These kind of characteristics of sedimentation, volcanic, and tectonic are believed to be good evidences of intra-arc basins (Bell and Suarez, 1993; Ingersoll, 1988; Miller, 1989).

Generally the characteristics of the intra-arc basins are easily broken (Ingersoll, 1988). After the formation of intra-arc tectonic environments, The Korean Peninsula experienced polyphase compressional and extensional tectonics (Chae and Chang, 1994; Hwang, 1994; Hwang and Angelier, 1992; Hwang et al., 1991; Kim, 1996; Lee, 1998; Lee et al., 1993). Furthermore, since Tertiary back-arc tectonic movements were developed in the East Sea located to the east of the Korean Peninsula. After the intra-arc tectonic environments during Cretaceous, extensional system was developed in Tertiary yielding back-arc basin East Sea. By the polyphase tectonic force and the back-arc related tectonic movements intra-arc tectonic characteristics of the Yongdong basin ceased to exist, and the basin evolved into a foreland basin since Tertiary (Lee, 1998).

\section{Summary}

Oblique subduction of the northward moving oceanic plate in the east of the Eurasian plate caused left-lateral fault belt and crustal depression in the Korean Peninsula. Terrigeneous alluvial and/or lacustrine sediments were deposited in the fault-bounded graben since Early Cretaceous. The Yongdong basin, one of terrigeneous sediments-filled graben, experienced migration of depocenter and could be characterized by two-mega sedimentary sequences. High rate of sedimentation, voluminous volcanogenic sediments, exclusive non-marine deposits, and plate-motionrelated transform setting strongly indicate that the Yongdong basin start as an intra-arc basin. Since Late Cretaceous, the basin is broken by polyphase compressional and extensional tectonic force, which 
was generated by E-W moving oceanic plate. Together with Yongdong basin, most other Cretaceous basins in the Korean Peninsula can now be explained in term of sinistral strike-slip faults and crustal- extension tectonics.

\section{Acknowledgments}

The author appreciates Prof. T.W. Chang of Kyungpook National University, Prof. S.J. Cho of Korea University and an anonymous reviewer for their useful comments.

\section{References}

Allen, J.R.L., 1984, Parallel lamination developed from upper-stage plane beds: A model based on the larger coherent structures of the turbulent boundary layer. Sedimentary Geology, 39, 227-242.

Allen, P.A., 1981, Sediments and processes on a small stream-flow dominated Devonian alluvial fan, Shetland Islands. Sedimentary Geology, 29, 31-37.

Aspler, L.B. and Donaldson, J.A., 1985, The Nonacho Basin (Early Proterozoic), northwest territories, Canada: Sedimentation and deformation in a strike-slip setting. In Biddle, K.T. and Christie-Blick, N. (eds.), Strike-slip deformation, basin formation, and sedimentation. Society of Economic Paleontologists and Mineralogists Special Publication, 37, Tulsa, Oklahoma, USA, 193-209.

Ballance, P.F., 1984, Sheetflow-dominated gravel fans of the non-marine middle Cenozoic Simmler Formation, central California. Sedimentary Geology, 38, 337-359.

Ballance, P.F. and Reading, H.G., 1980, Sedimentation in Oblique-slip Mobile Zones: An introduction. In Balance, P.F. and Reading, H.G. (eds.), Sedimentation in oblique-slip Mobile Zones. International Association of Sedimentologists Special Publication, 4, 1-5.

Bell, C.M. and Suarez, M., 1993, The depositional environments and tectonic development of a Mesozoic intra-arc basin, Atacama region, Chile. Geological Magazine, 130, 417-430.

Ben-Avraham, Z., 1989, Oceanic plateaus and the Pacific Ocean margins. In Ben-Abraham, Z. (ed.), The Evolution of the Pacific Ocean Margins. Oxford University Press, NY, USA, 7-19.

Bentham, P.A., Talling, P.J., and Burbank, D.W., 1993, Braided stream and flood-plain deposition in a rapidly aggrading basin: The Escanila formation, Spanish Pyrenees. In Best, J.L. and Bristow, C.S. (eds.), Braided River. Geological Society of Specical Publication, 75,
177-194.

Bluck, B.J., 1980, Evolution of strike-slip fault-controlled basin, Upper Old Red Sandstone, Scotland. In Balance, P.F. and Reading, H.G. (eds.), Sedimentation in Obliqueslip Mobile Zone. International Association of Sedimentologists Special Publication, 4, 63-78.

Boothroyd, J.C., 1972, Coarse-grained sedimentation on a braided Outwash Fan, Northeastern Gulf of Alaska. Coastal Research Division, University of South Carolina Technical Report No. 6, 127 p.

Boothroyd, J.C. and Nummedal, D., 1978, Proglacial braided outwash: A model for humid alluvial-fan deposits. In Miall, A.D. (ed.), Fluvial sedimentology Canadian Society of Petroleum Geologist Memoir, 5, 641668.

Bull, W.B., 1972, Recognition of alluvial fan deposits in the stratigraphic record. In Rigby, J.K. and Hamblin, W.K. (eds.), Recognition of Ancient Sedimentary Environments. Society of Economic Paleontology Mineral Special Publication, 16, 63-83.

Cant, D.J. and Walker, R.G., 1976, Development of a braided model for the Devonian Battery point sandstone, Quebec. Canadian Journal of Earth Science, 13, 102-119.

Cant, D.J. and Walker, R.G., 1978, Fluvial process and facies sequences in the sandy, braided South Saskatchewan River, Canada. Sedimentology, 25, 625648.

Chae, B.G. and Chang, T.W., 1994, Movement history of Yangsan fault and its related fractures at ChonghaYongdok Area, Korea. Journal of Geological Society of Korea, 30, 379-394. (in Korean)

Chang, K.H., 1977, Late Mesozoic stratigraphy, sedimentation and tectonics of southeastern Korea. Journal of Geological Society of Korea, 13, 76-90. (in Korean)

Chen, P., 1993, Timing of Displacement along the Tancheng-Lujiang Fault Zone and the Migration of Late Mesozoic Volcanism in Eastern China. In Xu, J. (ed.), The Tancheng-Lujiang Wrench Fault System. John Wiley and Sons, UK, USA, 105-111.

Choi, H.I., 1986, Sedimentation and evolution of the Cretaceous Gyeongsang (Kyongsang) Basin, southeastern Korea. Journal of Geological Society of London, 143, 29-40.

Choi, H.I. and Jin, M.S., 1988, Sedimentologic and Tectonic Evolution of the Gyeongsang Basin (abs.). 1st Symposium of the Korean Sedimentology Research Group, Seoul, Korea, p 1.

Chun, S.S. and Chough, S.K., 1992a, Depositional sequences from high-concentration turbidity currents, Cretaceous Uhangri Formation. In Chough S.K. (ed.), The Sedimentary basins in the Korean Peninsula and adjacent seas. Special Publication of Korean Sedimen- 
tology Research Group. Harnlimwon Publishing, Seoul, Korea, 60-76.

Chun, S.S. and Chough, S.K., 1992b, Tectonic history of Cretaceous sedimentary basins in the Southwestern Korean Peninsula and Yellow Sea. Proceedings of the second Korea-China international symposium on petroleum potential of the Yellow Sea and the East China Sea, 1-5.

Chun, S.S. and Lee, H.J., 1991, Basin analysis of the Cretaceous sedimentary basins: Depositional environments and depositional mechanism of the Kyokpo Basin. Korea Ocean Research and Development Institute, BSPE, 00233-348-5, $131 \mathrm{p}$.

Collinson, J.D., 1970, Bedforms of the Tana River, Norway. Geography Annal, 52A, 31-56.

Costa, J.E., 1974, Stratigraphic, morphologic, and pedogenic evidence of large floods in humid environments. Geology, 2, 301-303.

Costa, J.E., 1988, Rheologic, geomorphic, and sendimentologic differentiation of water floods, hyperconcentrated flows, and debris flows. In Baker, V.R., Kochel, B.C., and Patton, P.C. (eds.), Flood Geomorphology. John Wiley and Sons, New York, USA, 113-122.

Cruzel, D., Cadet, J., and Lapierre, H., 1990, Geodynamics of the Ogcheon Belt (South Korea). Tectonophysics, 183, 41-56.

Cui, S., Li, J., and Zhao, Y., 1985, On the Yanshenian movement of peri-Pacific belt in China and its adjacent areas. Scientific Papers on Geology for International Exchange-prepared for 27th International Geologic Congress, 2, 233-234.

DeCelles, P.G., Gray, M.B., Ridgway, K.D., Cole, R.B., Pivnik, D.A., Pequera, N., and Srivastava, P., 1991, Controls on syn-orogenic alluvial-fan architecture, Beartooth conglomerate (Paleocene), Wyoming and Montana. Sedimentology, 38, 567-590.

Emery, K.O., Hayashi, Y., Hilde, T.W.C., Kobayashi, K., Koo, J.H., Meng, C.Y., Niino, H., Osterhagen, J.H., Reynolds, L.M., Wageman, J.M., Wang, C.S., and Yang, S.J., 1969, Geological structure and some water characteristics of the East China Sea and the Yellow Sea. U.N. ECAFE CCOP, Technical Bulletin, 2, 3-43.

Fisher, R.V., 1971, Features of coarse-grained, high-concentration fluids and their deposits. Journal of Sedimentary Petrology, 41, 916-927.

Gloppen, T.G. and Steel, R.J., 1981, The deposits, internal structure and geometry in six alluvial fan-fan delta bodies bodies (Devonian-Norway) - A study on the significance of bedding sequence in conglomerates, In Biddle K.T. and Christie-Blick, N. (eds.), Strike-slip deformation, basin formation, and sedimentation. Society of Economic Paleontologists and Mineralogists Special Publication, 37, 177-192.
Harms, J.C., Southard, J.B., Spearing, D.R., and Walker, R.G., 1982, Structure and Sequence in Clastic Rocks. Society of Economic Paleontologists and Mineralogists Short Course, 9, 249.

Hein, F.J. and Walker, R.G., 1977, Bar evolution and development of stratification in the gravelly, braided kicking Horse River, British Columbia. Canadian Journal of Earth Science, 14, 562-570.

Heward, A.P., 1978, Alluvial fan sequence and megasequence models: With examples from Westphalian D Stephanian B coalfield Northern Spain. In Miall, A.D. (ed.), Fluvial Sedimentology Canadian Society of Petroleum Geologist Memoir. 5, Stacs Data Service, 669-702.

Hilde, T.W.C., Uyeda, S., and Kroenke, L., 1977, Evolution of the Western Pacific and its margin. Tectonophysics, 38, 145-152.

Hwang, J.H., 1994, Reconstruction of paleostress in the southeastern Korean Peninsula since the Early Cretaceous. Journal of Geological Society of Korea, 30, 2734.

Hwang, J.H. and Angelier, J., 1992, Paleostress reconstruction and the tectonic evolution of the Kyungsang Basin: A case example near Goryeong-eub. Journal of Geology of Korea, 28, 471-482.

Hwang, J.H., Angelier, J., and Cadet, J.P., 1991, Evolution tectonique polyphasee d'un basin continental: Le basin de Kyungsang (Coree). C.R. Academy Science of Paris, 313, Series II, 465-470.

Ingersoll, R.V., 1988, Tectonics of sedimentary basins. Geological Society of America Bulletin, 100, 17041719.

Kim, B.C., 1996, Sequential development of depositional systems in a strike-slip basin: Southern part of the Cretaceous Yongdong Basin. Ph.D. thesis, Yonsei University, Seoul, Korea, 336 p.

Kim, H.M., 1973, Paleocurrent analysis of the Yeongdong (Yongdong) Group, Southern Korea. Journal of Geological Society of Korea, 10, 1-24.

Kim, H.M., 1974, Sedimentation of the Yeongdong Group, Southern Korea. Journal of Geological Society of Korea, 10, 225-244.

Kim, J.Y., 1996, The study on metalliferous vein system and Early Cretaceous - Paleocene tectonic stress fields in the Kyeongsang Basin (1). Journal of Korean Earth Science Society, 17, 137-149.

Kim, K.B. and Hwang, J.H., 1986, Geological report of the Yongdong Sheet $(1: 50,000)$. Korea Institute Energy and Resources.

Kim, K.H. and Lee, J.S., 1993, Petrochemical studies of the Cretaceous volcanic rocks from the Kyeongsang (Kyongsang) sedimentary basin. Journal of Geological Society of Korea, 29, 84-96.

Kim, K.H., Nam, K.S., and Lee, J.H., 1990, Jurassic 
Paleo-magnetism of South Korea. Journal of Geological Society of Korea, 26, 513-526.

Kim, S.W., Lee, J.Y., Kim, Y.K., and Koh, I.S., 1991, Petrology of the Cretaceous Volcanic Rocks in Southern Yuchon Minor Basin (in Korean). Journal of Geological Society of Korea, 27, 24-39.

Klimetz, M.P., 1983, Speculations on the Mesozoic platetectonic evolution of eastern China. Tectonics, 2, 129166.

Koster, E.H., 1978, Experimental studies of coarse-grained sedimentation. Ph.D. Thesis, University of Ottawa, Canada, $177 \mathrm{p}$.

Kwon, B.D. Joo, J.A., and Kwon, J.H., 1993, Geophysical studies on major faults in the Ogcheon Belt: Gravity survey on the faults at Muan and Haenam areas. Journal of Geological Society of Korea, 29, 281-290.

Kwon, B.D. and Kim, K.J., 1994, Gravity and magnetic interpretation of Youngdong (Yongdong) basin Korea (abs). Fourth International Symposium and Field Excursion of IGCP, 321, Seoul Korea.

Lee, D.W., 1990, Sedimentation and tectonic evolution of the cretaceous Yongdong basin. Ph.D. Thesis, Korea University, Seoul, Korea, 273 p.

Lee, D.W., 1998, Strike-slip tectonics and basin formation during Cretaceous in the Korean Peninsula. Island Arc, 8, 218-231.

Lee, D.W., Chi, J.H., and Choh, S.J., 1992, Depositional environments of Northern part of the Cretaceous Yongdong basin, Korea. In Chough, S.K. (ed.), The Sedimentary basins in the Korean Peninsula and adjacent seas. Special Publication Korean Sedimentology Research Group (KSRG), Harnlimwon Publication, Seoul, Korea, 168-181.

Lee, D.W., Chi, J.H., and Lee, K.C., 1991, Stratigraphy of the strike-slip fault-controlled Yongdong basin, Korea: A genetic study in the northern part of the basin. Journal of Geological Society of Korea, 27, 246-258.

Lee, D.W. and Paik, K.H., 1989, Sedimentological characteristics along Yongdong Fault Zone in Cretaceous Yongdong basin. Journal of Geological Society of Korea, 25, 259-272

Lee, D.W. and Paik, K.H., 1990, Evolution of strike-slip fault-controlled Cretaceous Yongdong basin, South Korea: Signs of strike-slip tectonics during infilling. Journal of Geological Society of Korea, 26, 257-276.

Lee, G.D., Basse, J., Courtillot, V., and Montigny, R., 1987, Eastern Asia in the Cretaceous: New paleomagnetic data from South Korea and a new look at Chinese and Japanese data. Journal of Geophysical Research, 92, 3580-3596.

Lee, J.D., Kim, I.S., Yoon, S., Sang, K.N., and Kim, Y.H., 1993, Study on the Yangsang fault in Eonyang area with emphasis on fracturing and magnetic anisotropy.
Journal of Geological Society of Korea, 29, 128-144.

Lee, J.I., 1994, Evolution of granitic magmatism in the southern part of the Kyeongsang (Kyongsang) basin, Korea (abs.). 4th international symposium and field excursion, International Gorilla Conservation Programme, 321.

Lee, Y.J. and Kim, J.W., 1990, Characteristics of evolution trends of biotites in the Cretaceous to Tertiary granitic rocks of the southern Gyeongsang basin. Journal of Geological Society of Korea, 26, 133-142.

Lewis, D.W., Laird, M.G., and Lee, K.C., 1980, Debris flow deposits of early Miocene age, Deadman Stream, Marlborough, New Zealand. Sedimentary Geology, 27, 83-118.

Lorentz, J., 1980, Late Jurassic-Early Cretaceous sedimentation and tectonics of the Murzuq Basin, Southeastern Libya. In Salem, M.J. and Busrewil, M.T. (eds.), The Geology of Libya. 2, Academic Press, London, England, 383-392.

Lowe, D.R., 1976, Grain flow and grain flow deposits. Journal of Sedimentary Petrology, 46, 188-199.

Lowe, D.R., 1982, Sediment gravity flows II: Depositional models with special reference to the deposits of highdensity turbidity currents. Journal of Sedimentary Petrology, 52, 279-297.

Mader, D., 1985, Fluvial conglomerates in continental Red beds of the Buntsandstein (Lower Triassic) in the Eifel (F.R.G) and their palaeoenvironmental, palaeogeographical and palaeotectonic significance. Sedimentary Geology, 44, 1-64.

Maizels, J., 1993, Lithofacies variations within sand deposits: The role of runoff regime, flow dynamics and sediment supply characteristics. Sedimentary Geology, 85, 299-325.

Massari, F., 1984, Resedimented conglomerates of Miocene fan-delta complex, southern Alps, Italy. In Koster, E.H. and Steel, R.J. (eds.), Sedimentology of Gravels and Conglomerates. Canadian Society of Petroleum Geologists Memoir, 10, 259-278.

Mastalerz, K., 1995, Deposits of high-density turbidity currents on fan-delta slopes: An example from the upper Visean Szczawno Formation, Intrasudetic Basin, Poland. Sedimentary Geology, 98, 121-146.

McPerson, J.G., 1979, Calcrete (caliche) palaeosols in fluvial redbeds of the Aztec Siltstone (Upper Devonian), Southern Victoria land, Antarctica. Sedimentary Geology, 22, 267-285.

Miall, A.D., 1977, A review of the braided-river depositional environments. Earth Science review, 13, 1-62.

Miall, A.D., 1978, Lithofacies types and vertical profile models in braided river deposits: A summary. In Miall, A.D. (ed.), Fluvial Sedimentology Canadian Society of Petroleum Geologists Memoir. 5, Stacs Data Service, 
597-604.

Middleton, G.V. and Hampton, M.A., 1976, Subaqueous sediment transport and deposition by sediment gravity flows. In Stanley, D.J. and Swift, D.J.P. (eds.), Marine Sediment Transport and Environmental. Wiley, NY, USA, 197-218.

Miller, M.M., 1989, Intra-arc sedimentation and tectonism: Late Paleozoic evolution of the eastern Klamath terrane, California. Geological Society of America Bulletin, 101, 170-187.

Nemec, W., 1990, Aspects of sediment movement on steep delta slopes. In Colella, A. and Prior, D.B. (eds.), Coarse-Grained Deltas International Association of Sedimentologists Special Publication, 10, 29-73.

Nemec, W. and Steel, R.J., 1984, Alluvial and coastal conglomerates: Their significant features and some comments on gravelly mass-flow deposits. In Koster, E.H. and Steel, R.J. (eds.), Sedimentology of Gravels and Conglomerates. Canadian Society of Petroleum Geologists Memoir, 10, 1-32.

Nemec, W., Steel, R.J., Porebski, S.J., and Spinnavgr, A., 1984, Domba conglomerate, Devonian, Norway: Process and lateral variability in a mass flow-dominated, lacustrine fan-delta. In Koster, E.H. and Steel, R.J. (eds.), Sedimentology of Gravels and Conglomerates. Canadian Society of Petroleum Geologists Memoir, 10, 295-320.

Nilsen, T.H. and Mclaughin, R.J., 1985, Comparison of tectonic framework and depositional patterns of the Hornelen strike-slip basin of Norway and the Ridge and Little Sulphur Creek strike-slip basins of California. In Biddle, K.T. and Christie-Blick, N. (eds.), Strike-slip deformation, basin formation, and Society of Economic Paleontologists and Mineralogists Special Publication, 37, 79-103.

Otsuki, K., 1992, Oblique subduction, collision of microcontinents and subduction of oceanic ridge: Their implications on the Cretaceous tectonics of Japan. The Island Arc, 1, 51-63.

Paola, C., Wiele, S.M., and Reinhart, M.A., 1989, Upperregime parallel lamination as the result of turbulent sediment transport and low-amplitude bed forms. Sedimentology, 36, 47-59.

Park, Y.S., Kim, C.B., Yoon, C.H., and Ahn, K.S., 1997, The petrochemistry and geochronology of Cretaceous plutonic Rocks in the Koheung area, Chonnam. Journal of Korean Earth Science Society, 18, 70-83.

Pickering, K., Stow, D., Watson, M., and Hiscott, R., 1986, Deep-water facies, processes and models: A review and classification scheme for modern and ancient sediments. Earth Science Review, 23, 75-174.

Postma, G., 1984, Mass-flow conglomerates in a submarine canyon: Abrioja fan-delta, Pliocene, southeast
Spain. In Koster, E.H. and Steel, R.J. (eds.), Sedimentology of Gravels and Conglomerates. Canadian Society of Petroleum Geologists Memoir, 10, 237-258.

Postma, G., 1986, Classification for sediment gravity-flow deposits based on flow conditions during sedimentation. Geology, 14, 291-294.

Postma, G. and Cruickshank, C., 1988, Sedimentolgy of late Weichselian to Holocene terraced fan delta, Varangerfjord, northern Norway. In Nemec, W. and Steel, R.J. (eds.), Fan deltas: Sedimentology and Tectonic Settings. Blackie and Son, London, England, 144-157.

Prebble, W.M., 1980, Late Cainozoic sedimentation and tectonics of the East Coast Deformed Belt, in Marlborough. New Zealand, 4, 217-228.

Prior, D.B. and Bornhold B.D., 1988, Submarine morphology and processes of fjord fan deltas and related highgradient systems: Modern examples from British Columbia. In Nemec, W. and Steel, R.J. (eds.), Fan Deltas: Sedimentology and Tectonic Settings. Blackie and Son, London, England, 125-143.

Prior, D.B. and Bornhold B.D., 1989, Submarine sedimentation on a developing Holocene fan delta. Sedimentology, 36, 1053-1076.

Prior, D.B. and Bornhold B.D., 1990, The underwater development of Holocene fan deltas. In Colella, A. and Prior, D.B. (eds.), Coarse-Grained Deltas. International Association of Sedimentologists Special Publication, 10, 75-90.

Reading, H.G., 1980, Characteristics and recognition of strike-slip fault system. In Balance, P.F. and Reading, H.G. (eds.), Sedimentation in Oblique-slip Moblie Zone. Internatinal Association of Sedimentologists Special Publication, 4, 7-26.

Reinek, H.E. and Singh, I.B., 1980, Depositional sedimentary environments. Springer, NY, USA, 549 p.

Ritter, D.F., 1975, Stratigraphic implications of coarsegrained gravel deposited as overbank sediment, southern Illinois. Journal of Geology, 83, 645-650.

Rust, B.R., 1972, Pebble orientation in fluviatile sediments. Journal of Sedimentary Petrology, 25, 384-388.

Rust, B.R., 1978, Depositional models for braided alluvium. In Miall, A.D. (ed.), Fluvial Sedimentology. Canadian Society of Petroleum Geologist Memoir, 5, 602-625.

Rust, B.R. and Koster, E.H., 1984, Coarse alluvial deposits. In Walker, R.G. (ed.), Facies Models Geoscience Canada Reprint Series, 1, 53-69.

Sakai, T. and Okada, H., 1997, Sedimentation and tectonics of the Cretaceous sedimentary basins of the Axial and Kurosegawa Tectonic Zones in Kyushu, SW Japan. Memoirs of the Geological Society of Japan, 48, 7-28.

Shultz, A.W., 1984, Subaerial debris-flow deposition in the Upper Paleozoic Culter Formation, western Colorado. 
Journal of Sedimentary Petrology, 54, 759-772.

Simamura, S., 1927, Geologic map of Chosen, Yeongdong and Cheongsan sheet (1:50,000). Geological Survey of Chosen.

Smith, G.A., 1986, Coarse- grained non-marine volcaniclastic sediment: Terminology and depositional process. Geological Society of America Bulletin, 97, 1-10.

Smith, N.D., 1971, Transverse bars and braiding in Lower Platte River, Nebraska. Geological Society of America Bulletin, 82, 3407-3420.

Smith, N.D., 1974, Sedimentology and bar formation in the upper Kicking Horse River, a braided outwash stream. Journal of Geology, 82, 205-224.

Son, C.M., Cheong, C.H., Lee, S.M., and Um, S.H., 1969, A study on the sedimentary environments and geological structure of Korea. Research Report of Ministry of Science and Technology, 25-26.

Speksnijder, A., 1985, Anatomy of a strike-slip fault controlled sedimentary basin, Permian of the Southern Pyrenees, Spain. Sedimentary Geology, 44, 179-223.

Steel, R.J., 1974, New Red Sandstone floodplain and piedmont sedimentation in the Hebridean province, Scotland. Journal of Sedimentary Petrology, 44, 336-357.

Steel, R.J. and Gloppen, T.G., 1980, Late Caledoian (Devonian) basin formation, western Norway: Signs of strikeslip tectonics during infilling. In Balance, P.F. and Reading, H.G. (eds.), Sedimentation in Oblique-slip Mobile Zones. International Association of Sedimentologists Special Publication, 4, 79-103.

Steel, R.J., Maehle, S., Nilsen, H., Roe, S.L., and Spinnangr, A., 1977, Coarsening-upward cycles in the alluvium of Hornelen Basin (Devonian) Norway: Sedimentary response to tectonic events. Geological Society of America Bulletin, 88, 1124-1134.

Surlyk, F., 1984, Fan-delta to submarine fan conglomerates of the Volgian-Valanginian Wollastone Foreland Group, East Greenland. In Koster, E.H. and Steel, R.J. (eds.), Sedimentology of Gravels and Conglomerates Canadian Society of Petroleum Geologists Memoir, 10, 359-382.

Turner, B.R., 1980, Sedimentological characteristics of the Red "Muds" at Makapansgat Limeworks. Paleontology of Africa, 23, 51-58.

Utkin, V.P., 1975, On the wrench deformation of Central Sikhote-Alin. Geology of Far East, Science Center of Far East, Academy of USSR, Vladivostok, Russia, 515.

Utkin, V.P., 1978, The East Asian massive wrench belt, volcanic zone and marginal sea. Representative of Academy of USSR, 240, 400-403.

Utkin, V.P., 1984, The geodynamic condition of formation of continental marginal volcanic belt. Volcanic belt of
East Asia, Science Press, Moscow, Russia, 328-352.

Utkin, V.P., 1993, Wrench fault of Sikhote-Alin and Accretionary and Destructive Types of Fault Dislocation in the Asia-Pacific Transition Zone. In Xu, J. (ed.), The Tancheng-Lujiang Wrench Fault System. John Wiley and Sons, 225-237.

Walker, R.G., 1975, Conglomerate: Sedimentary structures and facies models. In Harms, J.C., Southard, J.B., Spearing, D.R., and Walker, R.G. (eds.), Depositional Environments as Interpreted from Primary Sedimentary Structures and Stratification Sequences. Society of Economic Paleontologists and Mineralogists, Short Course, 2, 133-158.

Walker, R.G., 1985, Mudstones and thin-bedded turbidites associated with the upper Cretaceous Wheeler Gorge Conglomerates, California: A possible channel-levee complex. Journal of Sedimentary Petrology, 55, 279290.

Watson, M.P., Hayward, A.B., Parkinson, D.N., and Zhang, Zh.M., 1987, Plate tectonic history, basin development and petroleum source rock deposition on shore China. Marine Petroleum Geology, 4, 205-225.

Wells, S.G. and Harvey, A.M., 1987, Sedimentologic and geomorphic variations in storm-generated alluvial fans, Howgill Fells, northwest England. Geological Society of America Bulletin, 98, 182-198.

Williams, P.F. and Rust, B.R., 1969, The sedimentology of a braided-river. Journal of Sedimentary Petrology, 39, 649-679.

Xu, J., Zhu, G., Tong, W., Cui, K., and Liu, Q., 1987, Formation and evolution of the Tancheng-Lujiang wrench fault system: A major shear system to the northwest of the Pacific Ocean. Tectonophysics, 134, 273-310.

Yanai, S., Park, B.S., and Otoh, S., 1985, The Honam Shear Zone (South Korea): Deformation and tectonic implication in the Far East. Scientific Papers of the College of Arts and Science, University of Tokyo, 35, 185-210.

Yin, A. and Nie, S., 1993, An indentation model for the North and South China collision and the development of the Tan-Lu and Honam fault systems, eastern Asia. Tectonics, 12, 801-813.

Zalan, P.V. and Davis, T.L., 1985, The Piaui Basin: Rifting and wrenching in an Equatorial Atlantic transform basin. In Biddle, K.T. and Christie-Blick, N. (eds.), Strike-slip deformation, basin formation, and sedimentation. Society of Economic Paleontologists and Mineralogists Special Publication, 37, 177-192.

Manuscript received: May 28, 2008

Revised manuscript received: April 15, 2009 Manuscript accepted: April 29, 2009 